\title{
Determinants of Dividend Policy: Evidence from GCC Market
}

\author{
B Rajesh Kumar ${ }^{1} \&$ K Abdul Waheed ${ }^{1}$ \\ ${ }^{1}$ Institute of Management Technology, Dubai, UAE \\ Correspondence: B Rajesh Kumar, Institute of Management Technology, Dubai Academic City, UAE, PO Box 345006. \\ Tel: 971- 4 4-227244 Ext.132. E-mail: rajesh155_bk@yahoo.com
}

Received: November 3, 2014

Accepted: November 17, 2014

Online Published: December 2, 2014

doi:10.5430/afr.v4n1p17

URL: http://dx.doi.org/10.5430/afr.v4n1p17

\begin{abstract}
This paper examines the determinants of dividend policy in GCC market based on sample firms in UAE market. An analysis was conducted to understand the dividend trends among different industry sectors in UAE market. The analysis of approximately 120 listed companies reveal that 80 per cent of the companies paid cash dividends during the three year period 2011-2013.

The paper also examines the various theoretical attributes used in financial literature to understand the determinants of dividend policy. The partial least squares structural equations modeling (PLS-SEM) was used to test the alternate explanations of corporate dividend payout policy in the gulf market. The study finds support for residual theory and pecking order argument of dividends. Investment policy influences dividend policy. The results support the theory that firms with high growth rate in income requires higher capital expenditure and establish lower dividend payout on account of costly external financing. Liquidity is an important determinant of dividend decision. Stability of dividend payments is not a critical factor considered by financial markets in the region.
\end{abstract}

Keywords: Dividends, Capital Expenditures, Liquidity, PLS-SEM, Dividend Theories

\section{Introduction}

The investment, financing and dividend decisions are the three main pillars of decision making in corporate finance. The dividend principle assumes that when firms don't have enough investments that earn their minimum required return or hurdle rate, then firms have to return the cash generated to the owners in the form of dividends. Basically there are three schools of thoughts on dividend policy. The dividend irrelevance theory advocated by Miller and Modigliani states that dividends do not affect the firm value. This theory is based on the assumption that dividends is not a tax disadvantage for an investor and firms can raise funds in capital markets for new investments without much issuance costs. The proponents of second school assumes that dividends are bad as they have a tax disadvantage for average shareholder and hence value of firm decreases when dividends are paid. Dividends create a tax disadvantage for investors who receive them when they are taxed much more heavily than price appreciation (capital gains). According to this viewpoint, dividend payments should reduce the returns to stockholders after personal taxes. The third school of thought states that dividends are good and can increase the value of the firm. Investors prefer dividends to capital gains since dividends are certain and capital gains are not. Risk averse investors will therefore prefer dividends. The clientele effect suggests that stockholders tend to invest in firms whose dividend policies match their preferences. This clustering of stocks in companies with dividend policies that match their preferences is called the client effect. Dividends also operate as an information signal to financial markets. The empirical evidence concerning price reactions to dividend increases and decreases is consistent at least on average with this signaling theory.

The basic objective of the study is to examine the various alternate dividend theories and insights in understanding corporate payout policies with reference to emerging markets like UAE. The study also aims to understand the dividend trends among the different industrial sectors in the UAE market. The study basically focuses on understanding the financial determinants of the dividend payout policies in the gulf region by examining the UAE market. 


\section{Theoretical Underpinnings and Review of Literature}

Under the residual theory of dividends, a negative relationship is expected between dividend payout and external financing costs. Investment policy of a firm is basically said to influence the dividend decisions. It can be assumed that firms which experience higher revenue growth entails higher investment expenditures. Therefore on account of costly external financing, firms tend to establish lower dividend payout. Moreover if managers expect higher growth rate in revenues in future, then the management is likely to retain funds for future capital expenditures by lowering the dividend payout. The Residual theory also postulates that a firm will pay dividends only when its internally generated funds are not completely used for investment purposes. Firms which experience high growth rates have large investment requirements. The pecking order advocated by Myers and Majluf (1984) hypotheses that growth firms should be characterized by low payout ratios. The average realized capital expenditure scaled by total assets , average growth rate in operating income, growth rate of revenues are proxies for growth variables. In this context it is hypothesized that dividend payout ratio is negatively related to both past growth of revenues and operating income, capital expenditure and forecasted future growth of revenues of the firm.

Higher the risk in terms of beta, firms have lower dividend payout as higher beta signals higher operating and financial leverage. Firms with higher fixed charges like interest payments pay lower dividends in order to avoid the cost of external financing through internal financing (retained earnings). Leverages produces fixed charges. Rozeff (1982) uses the equity beta to proxy for the cost of external financing. Firms use debt more frequently than equity when raising external capital. The dividend payments can be considered as substitutes for these charges. It can be hypothesized that other things equal, a firm having higher operating and financial leverage will choose a lower dividend payout policy in order to minimize the cost of external financing. Hence dividend payout ratio is negatively related to the firm's beta coefficient. Firm size measured as the log of total assets can also be used as proxy for the cost of external debt financing. A positive relationship is expected between size and dividend payout since larger firms face lower issuing costs.

The variability in capital structure indicates the firm's ability to have greater access to capital markets as firms will be able to switch between debt and equity and take advantage of lower transaction costs. This situation allows for more stable and higher dividend payments. It can be assumed that a positive relationship exists between dividend payout and variable representing variability in capital structure.

Another hypothesis that is being tested is that dividend payouts are a means to reduce agency costs when the outside shareholder's equity ownership is large and when the insider promoter's shareholding is less. Dividend payout ratio is positively related to the percentage of ownership of outside shareholders in the firm. Outside shareholders demand more dividends. Hence to reduce agency costs, firms pay higher dividend payouts. If the outside shareholders proportion of ownership is less and the insiders' ownership is more, then agency costs is reduced and firms pay lower dividends. Hence the dividend payout will be negatively related to the percentage of stocks held by insiders.

Signaling theory suggest that dividends convey information about the current or future level of earnings. Stability of cash flows can be related to dividend payout. Cash flow variability is measured as the OLS estimate of the coefficient of variation of cash flows for a period of three years. An inverse relationship is expected between CFV and DPR.

With respect to managerial considerations, it can be hypothesized that there exist a relationship between financial slack and dividend payout. Firms tend to increase their financial slack in order to maintain their ability to undertake profitable investments thereby reducing dividend payments. Financial slack is expected to be inversely related to dividend payout ratio.

Liquidity is an important determinant of dividend decision. If a company has enough cash flows, it would like to distribute cash dividends in order to reduce agency costs. Profitability can also be related to dividend decision. Higher the profitability of companies, greater would be the propensity to give dividends.

Lintner (1956) suggests that firms have target payout ratios and adjust dividends to earnings with a lag. The study finds three consistent patterns. Firstly the firms set target dividend payout ratios by determining the fraction of earnings which would be paid out as dividends in long term. Secondly they change dividends to match long term and sustainable shifts in earnings. Thirdly the study finds that managers are much more concerned about changes in dividends than about the level of dividends. Fama and Baiak (1968) confirmed Linter's findings that dividend changes tend to follow earnings changes. 
Miller and Modigliani (1961) establish the irrelevance of dividend policy in a perfect capital market. The study finds that dividend policy is irrelevant in valuing the current worth of shares in the context of irrational assumptions, market perfections, zero transaction costs and indifferent behavior of investors.

Higgins (1972) employs a model which utilizes the firm's cash flow constraint and its optimal debt equity ratio to derive an expression which relates dividends to profits and investment. The Higgin model suggests that the optimal payout is a function of residual dividend policy combined with the minimization of the sum of the costs of "excessive current assets" and the costs of external equity financing. This study also suggests that the dividend payout of firms is influenced by factors like the fund requirement for investment purposes and debt financing requirements. Fama (1974) finds support for the fact that investment influences dividend policy. Miller and Scholes (1978) present sufficient conditions for taxable investors to be indifferent to dividends despite tax differentials in favor of capital gains.

Macabe (1979) suggests that new long term debt have a negative influence on the dividend policy. Rozeff (1982) suggest that investment policy influences dividend policy. The study suggests that agency costs decline as dividend payout is increased but at the same time the transaction costs of financing increases. In such a case an optimum cost can be derived at a lower dividend payout ratio. The model results of the study suggest that dividend payout is negatively related to the firm's past and expected future growth rate of sales, beta coefficient, percentage of stock held by insiders and significantly positively related to the number of stock holders. The study by Kasim et al (1993) finds strong support for the transaction cost/residual theory of dividends, pecking order argument and role of dividends in mitigating agency problems. The study also finds that firms with financial flexibility that maintain stable dividends pay higher dividends.

The tax clientele argument postulated by studies like Elton and Gruber (1970), Litzenberger and Ramaswamy (1979), Brennan (1990), DeAngelo and Masulis (1980), that investors in low tax brackets prefer high dividend paying stocks when compared to investors in high tax brackets. Study by Sterk and Vandenberg (1990) find a preference for cash dividends despite the elimination of different tax rates between capital gains and dividend income.

Kale and Nole (1990) suggest that dividends are used to signal the quality of the firm's cash flows. Aharony et al (1980) shows that managers use cash dividend announcements to signal changes in their expectations about future prospects of the firm. The study by Asquith et al (1983) investigates the impact of dividends on stock holder's wealth by analyzing 168 firms that either pay the first dividend in their corporate history or initiate dividends after a 10 year hiatus. The empirical results exhibit larger positive excess returns. Miller et al (1982) extend the standard finance model of the firm's dividend decisions by allowing the firm's managers to know more than outside investors about the true state of the firm's current earnings. The studies by Bhattacharya (1979), John and Williams (1985) and Kane, Lee and Marcus (1984) finds that dividends can convey information about the current or future level of earnings. The empirical studies by Watts (1973), Gonedes (1978), Penman (1983), Kumar (1988) indicates that dividends are not good predictors of the firm's future earnings.

Dividends can be used in reducing the agency problem between managers and stockholders. Jensen and Meckling (1976) define the concept of agency costs and investigate the nature of agency costs generated by the existence of debt and equity. In this seminal paper, Jensen puts forward the view that payment of dividends reduces the discretionary funds which are available to managers and helps to reduce the agency conflict which exist between managers and stockholders. Crutchley (1989) suggest that equity agency costs can be reduced by increasing dividends. The paper by Easterbrook (1984) examines whether dividends are a method of aligning managers' interest with those of investors and offers agency cost explanations of dividends. Jensen et al (1992) finds that high insider ownership firms choose lower levels of both debt and dividends. Their results suggest that the effects of profitability, growth and investment spending on debt and dividend policy support a modified "pecking order" hypothesis.

The studies by Linter(1956), Baker et al (1985), Fama and Babiak (1968), Laub (1976) finds that firms prefer a certain degree of stability in dividend payments. Titman and Wessels (1988) suggest that firms having more collateralizable assets have fewer agency problems between bondholders and stockholders as these assets serve as collateral against borrowing. Therefore a positive relationship is expected between the ratio of net plant to total assets and dividend payout.

Benito and Young (2001) find that liquidity and dividend payment behavior of a company have a direct relationship. Deshmukh (2005) examine the effect of asymmetric information on dividend policy in light of an alternative explanation based on the pecking order theory. The study finds evidence for the fact that dividends are inversely related to the level of asymmetric information. This finding is consistent with the pecking order theory, but inconsistent with the signaling theory. 
The study by Denis et al (2008) using sample countries over the period 1994-2002 finds that in countries like US, Canada, UK, France and Japan, the propensity to pay dividends is higher among larger more profitable firms and for those which retained earnings comprise a large fraction of total equity. The study supports agency cost based life cycle theories and cast doubt on signaling, clientele and catering explanations for dividends.

The empirical paper by Kuo et al (2013) study the determinants of dividend payout policy and examine the role of liquidity, risk and catering in explaining the propensity to pay. The results indicate that risk play a major role in firms' dividend policy. The study further points that liquidity is an important determinant of dividend payout policy in developed markets of US and Europe.

\section{Survey Results}

There are 66 listed companies each in the Dubai Financial Market and Abu Dhabi stock exchange. The survey of approximately 120 companies listed in these stock exchanges reveal that 80 per cent of the companies paid cash dividends during the three year period 2011-2013.

Table 1. Dividend Statistics

\begin{tabular}{ll}
\hline Year & $\begin{array}{l}\text { Amount of dividends in } \\
\text { million dollars }\end{array}$ \\
\hline 2011 & 4798.36 \\
2012 & 5354.12 \\
2013 & 6865.29 \\
Total & 17017.78 \\
\hline
\end{tabular}

Ninety six firms listed in DFM and ADX have paid approximately $\$ 17$ billion as cash dividends to shareholders during the three year period of study. The amount of dividend payment increased by $28 \%$ in the year 2013 compared to the year 2012. The average growth rate of dividends during the two last two year period was approximately 20 per cent. The average dividend payout by 67 companies was 44.7 per cent.

Table 2. Trends of Dividend Payment -Major Sectors

\begin{tabular}{lllll}
\hline Sector & $\begin{array}{c}\text { Number } \\
\text { of } \\
\text { companies }\end{array}$ & $\begin{array}{c}\text { Total dividends } \\
\text { in amount of million } \\
\text { dollars } \\
(2011-2013)\end{array}$ & $\begin{array}{l}\text { Three year } \\
\text { average DPO }\end{array}$ & $\begin{array}{l}\text { Three year average } \\
\text { Dividend/Total } \\
\text { Assets }\end{array}$ \\
\hline Banking & 24 & 8486.95 & $35.8 \%$ & $0.56 \%$ \\
Insurance & 21 & 346.29 & $49.3 \%$ & $1.21 \%$ \\
$\begin{array}{l}\text { Investment } \\
\text { and }\end{array}$ & 4 & 235.16 & $35.8 \%$ & $1.33 \%$ \\
$\begin{array}{l}\text { Financial } \\
\text { Services }\end{array}$ & & & \\
$\begin{array}{l}\text { Industry } \\
\text { and Hotel }\end{array}$ & 27 & 1362.92 & $32.32 \%$ & $0.62 \%$ \\
Services & 15 & 6586.49 & $53.6 \%$ & $2.86 \%$ \\
\hline
\end{tabular}

Out of 27 listed banks, 24 have paid dividends in one or more years during the three year period of study. Among 28 listed insurance companies, 21 have paid cash dividends during one or more year of study. Out of 10 Investment and financial services companies, four companies had paid dividends during the period 2011-2013. Out of 34 listed companies, 27 companies paid dividends during the last three year period. Out of 18 listed companies in the services sector, 15 companies paid dividends during the last three year period.

Service sector had the highest dividend payout during the three year period .In terms of dividend by total assets ratio, service sector had the highest value with 2.86 per cent of assets value distributed as dividends. In service sector excluding the highest dividend paying company Etisalat, the dividend payout during the last three years was 31.2 per cent. In terms of total dividends paid, banking sector is the front runner followed by the services sector. In terms of 
average values, service sector leads with dividend payment of 439 million dollars followed by banking sector with average value of $\$ 353.62$ million.

Table 3. Top dividend Paying Banks 2011-2013

\begin{tabular}{lll}
\hline Sl & Banks & Total Dividend in million dollars \\
\hline 1 & First Gulf Bank & 1315.03 \\
2 & NBAD One Share ETF & 1074.59 \\
3 & ADCB & 1114.48 \\
4 & Emirates NBD & 986.34 \\
5 & National Bank of Abu Dhabi & 802.76 \\
\hline
\end{tabular}

Table 4. Top dividend Paying Insurance Companies 2011-2013

\begin{tabular}{lll}
\hline S1 & Insurance Companies & Total Dividend in million dollars \\
\hline 1 & Emirates Insurance Co & 66.39 \\
2 & Al Ain Ahlia Insurance Co & 45.08 \\
3 & Orient Insurance PJSC & 36.88 \\
4 & Al Dhafra Insurance Co & 33.46 \\
5 & National General Insurance Co & 24.59 \\
\hline
\end{tabular}

Table 5. Top dividend paying companies in Investment and Financial Services

\begin{tabular}{lll}
\hline S1 & Companies & Total Dividend in million dollars \\
\hline 1 & Dubai Investments PJSC & 175.57 \\
2 & Dubai Financial Market PJSC & 51.12 \\
3 & Gulf Livestock Company & 8.19 \\
\hline
\end{tabular}

Table 6. Top dividend paying companies in Industry and hotels

\begin{tabular}{lll}
\hline S1 & Companies & Total Dividend in million dollars \\
\hline 1 & Emaar Properties PJSC & 485.65 \\
2 & $\begin{array}{l}\text { Abu Dhabi National Energy } \\
\text { Company }\end{array}$ & 326.50 \\
3 & $\begin{array}{l}\text { Eshraq properties Co } \\
4\end{array}$ & $\begin{array}{l}\text { National Corp for Tourism and } \\
\text { hotels }\end{array}$ \\
5 & Abu Dhabi National Hotels & 54.39 \\
\hline
\end{tabular}

The industry sector consists of telecommunication, cement industry, infrastructure, hotels, ship building, energy and properties.

Table 7. Top dividend paying companies in service sector

\begin{tabular}{lll}
\hline S1 & Companies & Total Dividend in million dollars \\
\hline 1 & Etisalat & 4361.37 \\
2 & Emirates Integrated Telecom & 836.83 \\
3 & Ooredoo & 344.62 \\
4 & Air Arabia & 267.75 \\
5 & Agility The Public Warehousing & 252.62 \\
& Company \\
\hline
\end{tabular}


Etisalat had paid the highest dividend of amount of $\$ 4361.37$ during the period 2011-2013. First Gulf Bank and Abu Dhabi Commercial Bank were the next highest dividend paying companies in UAE. Banking and Service sector constituted the maximum dividend paying sectors in UAE market.

Table 8. Top 10 Companies in terms of DPO

\begin{tabular}{llll}
\hline SL & Company & Sector & Average DPO 2011-2013 \\
\hline 1 & Al Ain Al Ahlia & Insurance & $112.3 \%$ \\
& Insurance Co & & \\
2 & Umm Al Qaiwain & Industry & $104.2 \%$ \\
& Cement Industries & & \\
3 & Al Buhaira National & Insurance & $102.7 \%$ \\
& Insurance Company & & \\
4 & Ras Al Khaimah Cement & Industry & $98.7 \%$ \\
& Company & & \\
5 & Air Arabia PJSC & Services & $94.4 \%$ \\
6 & Etisalat & Services & $86.2 \%$ \\
7 & Al Dhafra Insurance & Insurance & $85.8 \%$ \\
9 & Emirates Insurance & Insurance & $83.5 \%$ \\
9 & National Corp for & Industry & $78.9 \%$ \\
& Tourism and Hotels & & $77.1 \%$ \\
\hline
\end{tabular}

Three companies have paid more than 100 per cent of their earnings as dividends. Ras Al Khaimah Cement Company paid approximately 99 per cent of its average earnings as dividends during the three year period of study. Air Arabia paid 94 per cent of its earnings as dividends during the three year period. The highest dividend paying company Etisalat had an average dividend payout of 86.2 per cent during the three year period 2011-2013.

\section{Data and Methodology}

The initial sample size was 127 companies. Companies with DPO greater than one and scaling variables with negative values were removed. Seven companies were eliminated due to the above mentioned condition. Sixteen companies were eliminated from the sample due to non-availability of data. Seven companies were removed since variables or scaling factors were negative. 12 firms were removed from the sample due to extreme outlier values. The final selection criteria involved choosing firms with average dividend payout of at least 25 per cent. This resulted in elimination of further 42 companies. Hence the final sample size was 50 . The final sample consisted of 16 companies from banking sector, 12 from industry and hotel segments, 11 from insurance, 8 from services and three from investment and financial services. The average DPO of the sample firms were 54.9 per cent. The average and median market capitalization of the sample firms were $\$ 324.84$ billion and $\$ 1.28$ billion respectively. The mean and median of the total net profits of the sample firms during the three year period was $\$ 0.409$ billion and $\$ 0.210$ billion.

Generally empirical studies involving dividends analyze the determinants of dividends using regression analysis in which some measure of dividend as the dependent variable and the independent variables as proxies of unobservable attributes. This technique in which considering various theoretical attributes as if they are mutually exclusive could lead to spurious correlations or misspecification problems. Studies have used two step procedure that involves factor analysis and multiple regression to understand the determinants of dividend payment. (Kasim et al 1993)

The structural equation modeling (SEM) procedure that simultaneously measure both measurement and structural model was used for our study (Titman \& Wessels 1988).

The SEM procedure can be done in two ways, namely, covariance-based structural equation modeling (CB-SEM) and partial least squares structural equations modeling (PLS-SEM). Recently, there is an increased use of PLS-SEM rather than CB-SEM due to both theoretical and methodological reasons (Hair et al., 2012). With respect to theoretical reasons, the PLS-SEM can be used to extend the existing theory. With respect to methodological reasons, CB-SEM models require larger sample size and normal data for better goodness of fit indices in comparison with 
PLS-SEM (Chin et al., 2003; Hulland, 1999; Hair et al., 2012; Wetzels et al., 2009). We employed PLS-SEM using SmartPLS software (Ringle et al., 2005), as the purpose of our study is to extend structural theory on dividend payout behavior among UAE companies which is a sufficient condition for using PLS-SEM in comparison with CB-SEM (Hair et al., 2012). Furthermore, the sample size of our study is very small $(n=50)$ and the data was also found to be non-normal as we checked the normality using Kolmogorov-Smirnov test (Hair et al., 2012).

Table 9. Summary Statistics of Cross sectional variables

The table below gives the summary statistics of cross section variables of the final sample. The variables are described in Appendix A.

\begin{tabular}{lllll}
\hline Variable & Mean & $\begin{array}{l}\text { Standard } \\
\text { Deviation }\end{array}$ & Minimum & Maximum \\
\hline DPO & 0.549 & 0.21 & 0.271 & 0.987 \\
LNTA & 3.67 & 0.87 & 2.35 & 5.49 \\
BETA & 0.48 & 0.48 & -0.03 & 1.79 \\
CAPEX/TA & 0.0219 & .033 & 0.1280 & 0.00 \\
OIG & 0.09 & 0.74 & -1.16 & 4.65 \\
SDLEV & 0.33 & 0.55 & 0.00 & 2.15 \\
CFV & 13.46 & 33.96 & -1.79 & 143.27 \\
NPTA & 0.16 & 0.22 & 0.00 & 0.72 \\
LIQ & 0.33 & 0.40 & 0.00 & 1.62 \\
STABDIV & 0.68 & 0.47 & 1.00 & 0.00 \\
DER & 2.38 & 3.27 & 0.00 & 13.60 \\
TOBIN Q & 0.53 & 0.44 & 0.07 & 2.33 \\
SG & 0.24 & 1.50 & -0.89 & 10.43 \\
P/E & 13.78 & 18.46 & -6.25 & 122.43 \\
P/B & 0.53 & 0.44 & 0.07 & 2.33 \\
CR & 2.49 & 5.08 & 0.24 & 35.36 \\
NPR & 0.85 & 3.90 & -0.03 & 27.26 \\
ROI & 0.11 & 0.09 & -0.01 & 0.49 \\
PBIT/TA & 0.05 & 0.05 & -0.01 & 0.18 \\
MARCAP(mn) & 6496.85 & 13193.82 & 152.92 & 78613.39 \\
REE & 0.23 & .2206 & 0.79 & -0.77 \\
INSIDER & 0.50 & 0.21 & 1.00 & 0.01 \\
FII & 0.11 & 0.16 & 0.78 & 0.00 \\
\hline DPO of & $5 a p$ & & \\
\hline
\end{tabular}

The average DPO of the sample firms was approximately 55 per cent. The average capital expenditure relative to total assets was approximately 2.19 per cent. The average promoter holding in UAE sample firms were approximately 50 per cent whereas that of foreign financial institutions was 11 per cent.

\section{Results \& Interpretation}

Table 10 provides the results of measurement model in which factor loadings of respective observed variable with its theorized latent factor is presented. In PLS-SEM, the significance of the factor loadings are assessed by the bootstrapping procedure with minimum samples of 5000 and number of cases equivalent to sample size ( $\mathrm{n}=50$ ) (Ringle et al., 2005). In the initial analysis, we checked all the variables with its respective latent factors according the existing theory on dividend payout. The variables such as Beta, Tobin Q, DER, FII, NPTA, net profit ratio, ROI, PBIT/TA, SG and OIG were found to be either not significantly loading with their respective factor or negatively load with their respective factors. Therefore, we removed these variables from subsequent analysis. The variables such as LIQ, CR, LNTA, REE, INSIDER,CAPEX/TA, SDLEV,OIG, CFV and STABDIV were found to be 
significantly loaded with their respective factor (factor loading $>0.40$ with $\mathrm{t}$-value $<0.05$ level) and also found to have less cross loading with other factors which establishes that these factors could be satisfactorily used as independent factors for further analysis. This can be further validated by checking inter-factor correlations as presented in Table 10. The inter-factor correlations were found to be less than 0.6.

Table 10. PLS-SEM Outer loadings \& cross loadings (Measurement Model)

\begin{tabular}{|c|c|c|c|c|c|c|c|}
\hline $\begin{array}{l}\text { Observed } \\
\text { variables / } \\
\text { Latent factors }\end{array}$ & $\begin{array}{l}\text { Financial } \\
\text { Slack }\end{array}$ & Liquidity & $\begin{array}{l}\text { Transaction } \\
\text { Costs }\end{array}$ & $\begin{array}{l}\text { Ownership } \\
\text { dispersion }\end{array}$ & $\begin{array}{l}\text { Residual/Pecking } \\
\text { order }\end{array}$ & Signaling & $\begin{array}{l}\text { Dividend } \\
\text { stability }\end{array}$ \\
\hline$L I Q$ & 1.00 & -0.18 & 0.59 & 0.03 & 0.05 & 0.40 & 0.26 \\
\hline \multicolumn{8}{|l|}{ Liquidity } \\
\hline$C R$ & -0.18 & 1.00 & -0.28 & -0.02 & -0.17 & -0.10 & 0.09 \\
\hline \multicolumn{8}{|l|}{$\begin{array}{l}\text { Transaction } \\
\text { costs }\end{array}$} \\
\hline 1. LNTA & 0.61 & -0.26 & $0.90^{*}$ & -0.11 & 0.17 & 0.42 & 0.35 \\
\hline 2. $R E E$ & 0.06 & -0.08 & $0.40^{*}$ & 0.24 & -0.03 & 0.10 & 0.09 \\
\hline \multicolumn{8}{|l|}{ Ownership } \\
\hline INSIDER & 0.03 & -0.02 & 0.00 & 1.00 & 0.01 & 0.18 & 0.11 \\
\hline \multicolumn{8}{|l|}{ Residual/ } \\
\hline \multicolumn{8}{|l|}{$\begin{array}{l}\text { Pecking } \\
\text { Order }\end{array}$} \\
\hline 1. CAPEX/TA & -0.22 & -0.09 & -0.07 & -0.06 & $0.58 *$ & 0.05 & 0.20 \\
\hline 2. $S D L E V$ & 0.35 & -0.12 & 0.30 & -0.10 & 0.43 * & 0.11 & 0.22 \\
\hline 3. $O I G$ & 0.00 & -0.06 & 0.02 & 0.16 & $0.58 *$ & 0.05 & 0.15 \\
\hline \multicolumn{8}{|l|}{ Signaling } \\
\hline$C F V$ & 0.40 & -0.10 & 0.43 & 0.18 & 0.13 & 1.00 & 0.21 \\
\hline \multicolumn{8}{|l|}{$\begin{array}{l}\text { Dividend } \\
\text { stability }\end{array}$} \\
\hline STABDIV & 0.26 & 0.09 & 0.36 & 0.11 & 0.35 & 0.21 & 1.00 \\
\hline
\end{tabular}

$* p$ value $<0.05$ level

To test the effect of latent factors on DPO, the results of structural model need to be examined. In PLS-SEM, the structural model is examined on the explanatory power of the entire model, the predictive power of independent variables and predictive relevance (Hair et al., 2012). Firstly, with respect to explanatory power of the structural model is assessed by R2 value which explains the variance in the dependent variable by the independent variable(s). The structural model of our study explains $24 \%$ of variance $(R 2=0.24)$ in the dependent variable, DPO. The result is considered to be moderate considering the restrictions of sample size (Hair et al., 2012). In PLS-SEM, the predictive power is assessed by the significance of path coefficients (Hair et al., 2012). The latent factors such as liquidity (path coefficient $=0.16$ with $\mathrm{t}$-value $<0.05$ level), residual theory $/$ pecking order (path coefficient $=-0.19$ with $\mathrm{t}$-value $<0.05$ level) and dividend stability (path coefficient $=-0.23$ with t-value $<0.05$ level) were found to be significantly affect DPO. Finally, the predictive relevance was assessed by Stone-Geisser's nonparametric test (Geisser 1975; Stone 1974) with Q2 value by using blindfolding approach in SmartPLS (Ringle et al., 2005; Hair et al., 2012). The Q2 value is required to exceed zero to confirm the predictive relevance. The model of our study derived a Q2 value of 0.24 that confirms the predictive relevance of model of our study. 
Table 11. PLS-SEM Structural model and Inter-construct correlations

\begin{tabular}{|c|c|c|c|c|c|c|c|c|c|c|}
\hline \multirow[t]{2}{*}{ Factors } & \multirow{2}{*}{$\begin{array}{l}\text { Path } \\
\text { coefficients }\end{array}$} & \multirow[t]{2}{*}{$\mathrm{t}$-value } & \multirow[t]{2}{*}{ p-value } & \multicolumn{7}{|c|}{ Inter-factor correlations } \\
\hline & & & & $\begin{array}{l}\text { Financial } \\
\text { slack }\end{array}$ & Liquidity & $\begin{array}{l}\text { Transaction } \\
\text { costs }\end{array}$ & $\begin{array}{l}\text { Ownership } \\
\text { dispersion }\end{array}$ & $\begin{array}{l}\text { Pecking } \\
\text { order/Resi } \\
\text { dual }\end{array}$ & Signal & $\begin{array}{l}\text { Dividend } \\
\text { stability }\end{array}$ \\
\hline \multicolumn{2}{|c|}{ Financial slack 0.03} & 0.36 & 0.36 & 1.00 & & & & & & \\
\hline Liquidity & 0.16 & 1.71 & 0.05 & -0.18 & 1.00 & & & & & \\
\hline $\begin{array}{l}\text { Transaction } \\
\text { costs }\end{array}$ & -0.19 & 1.15 & 0.13 & 0.59 & -0.28 & 1.00 & & & & \\
\hline $\begin{array}{l}\text { Ownership } \\
\text { dispersion }\end{array}$ & -0.06 & 0.68 & 0.25 & 0.03 & -0.02 & 0.00 & 1.00 & & & \\
\hline $\begin{array}{l}\text { Pecking } \\
\text { order/Residua }\end{array}$ & -0.19 & 1.66 & 0.05 & 0.05 & -0.17 & 0.14 & 0.01 & 1.00 & & \\
\hline Signaling & -0.01 & 0.16 & 0.44 & 0.40 & -0.10 & 0.43 & 0.18 & 0.13 & 1.00 & \\
\hline $\begin{array}{l}\text { Dividend } \\
\text { stability }\end{array}$ & -0.23 & 1.74 & 0.04 & 0.26 & 0.09 & 0.36 & 0.11 & 0.35 & 0.21 & 1.00 \\
\hline
\end{tabular}

The results the residual and pecking order argument of dividend theories. LNTA and DPO are expected to have positive relationship since larger firms have lower issuing costs. But the results show negative relationship with no statistical significance. The residual dividend theory states that firms will pay dividends only when its internally generated funds are not utilized for investment activities. Moreover firms having higher growth rates have larger investment requirements. The proxy variable of CAPEX/TA (Three year average capital expenditure scaled by total assets) and OIG (Three year average growth in operating income) have significant positive loadings on the factor termed pecking order. An inverse relationship between DPO and both CAPEX/TA and OIG is expected. The results can be interpreted to confirm the same. The pecking order factor variables CAPEX/TA and OIG have significant path coefficient with value of -0.19 . Thus a negative relationship is established between pecking order factor and dividend payout. Firms with high growth rate in operating income signifying higher investment opportunities are expected to have more capital expenditures. Firms with these characteristics are not likely to pay much in dividends. In other words firms with higher capital expenditures are expected to pay fewer dividends.

Signaling factor is represented by the variable of cash flow variance (CFV). Firms with less volatile cash flows may pay higher dividends. A negative relationship between CFV and DPO is found but the path coefficient is statistically insignificant.

The variable SDLEV have significant positive loadings on factor pecking order. This variable is the standard deviation of the capital structure changes for the three year period. It is measured as the standard deviation of debt equity ratio for three year period. Firms having greater flexibility to switch between debt and equity market will be able to take advantage of lower transaction costs and hence possibly pay higher dividends. But negative relationship is established between SDLEV and DPO contrary to expected lines.

The variable current ratio have positive loading on factor termed liquidity. Liquidity and Dividend Payout is positively related .Liquidity factor have path coefficient value of 0.16 . Hence it can be concluded that liquid firms tend to pay more dividends.

Firms are expected to maintain a certain degree of stability in dividend payment .A dummy variable of $0-1$ is used to measure stability of dividend. A value of 1 is given if the dividends of past three years have been consistently higher than 90 per cent of the previous year or 0 otherwise. The factor dividend stability represented by variable STABDIV has negative significant relationship with dividend payout. The path coefficient value was -0.23 with significance at 5 per cent level. This result is quite puzzling. Firms with stable dividend payments may tend to pay lower dividends in future. It may be concluded that stability of dividend payments is not a critical factor considered by investors in financial markets of Gulf region like UAE. 
The factor ownership dispersion represented by variable INSIDER have negative relationship with DPO. INSIDER is measured as the percentage of ownership of the main promoters in the firm. Higher the INSIDER ownership, lower is the dividend payout. Higher INSIDER levels leads to lower agency problems. Hence an inverse relationship is expected between INSIDER and DPO. But the results are not statistically significant (the path coefficient of -0.06 is not statistically significant).

\section{Conclusion}

The results tend to support the residual and pecking order argument of dividend theories put forward by various earlier academic studies. Dividend payout ratios are expected to be inversely related to the cost of external funds (equity and debt), investment outlays and growth. Under the residual theory of dividends, a negative relationship is expected between payout and external financing transaction costs. Firm size measured by the natural log of total assets (LNTA) is used as a proxy for the cost of external debt financing. Firms with large asset sizes may also have higher retained earnings relative to the equity capital. Firm size and retained earnings have significant positive loadings on factor termed transaction costs. The path coefficient for factor transaction costs is negative with respect to dividend payout .Hence it can be implied that firms with high retained earnings to equity may use the internal funds for capital investments to avoid costly external financing rather than paying dividends. But the results are not statistically significant. The study finds that there exist inverse relationship between dividend payout ratio and both capital intensity and operating income growth. Thus it can be stated that firms pay dividends only when its internally generated funds are not utilized for investment activities. Firms having higher growth rates have larger investment requirements. Based on significant path coefficient values, negative relationship is established between pecking order factor and dividend payout. Firms which experience high growth rate in revenues require higher capital expenditures for expansion to account for increased operating activities. On account of costly external financing such firms tend to establish lower dividend payout by retaining funds rather than paying to investors as dividends. Liquid firms tend to pay more dividends.

This study supports the residual and pecking order argument in line with other academic studies. In addition the study liquid firm tends to pay more dividends. The study suggest that stability of dividends is not a critical determinant for the dividend payout policy of UAE based companies.

\section{Future Directions}

The study can be extended to include sample firms from different GCC countries to understand the determinants of dividend policy in a larger perspective. Comparison studies of dividend policies between other emerging markets and developed markets could shed new ideas on the determinants of the dividend policies. 


\section{Appendix A}

The variables were three year average values (2011-2013 period)

\begin{tabular}{|c|c|}
\hline Variable & Description \\
\hline DPO & $\begin{array}{l}\text { Three year average Dividend Payout Ratio. The average is for period } \\
\text { 2011-2013. }\end{array}$ \\
\hline LNTA & Natural log of Total Assets. Three year average (2011-2013) was used. \\
\hline BETA & The firm's average beta computed using monthly returns \\
\hline CAPEX/TA & $\begin{array}{l}\text { Proxy for average expected capital expenditures scaled by average total assets } \\
\text { during the three year period. }\end{array}$ \\
\hline $\mathrm{OIG}$ & Average growth rate in operating income during the period 2011-2013 \\
\hline SDLEV & $\begin{array}{l}\text { Proxy for the measure of standard deviation of changes in debt equity ratio } \\
\text { during the three year period 2011-2013 }\end{array}$ \\
\hline $\mathrm{CFV}$ & Coefficient of Variation of cash flows during the three year period \\
\hline INSIDER & $\begin{array}{l}\text { Proxy for agency costs of ownership. Proportion of main promoters holdings in } \\
\text { the ownership structure }\end{array}$ \\
\hline FII & Proportion of foreign institutional holdings in the ownership structure \\
\hline NPTA & $\begin{array}{l}\text { Proxy for agency cost of debt. The variable measures the collaterizable value of } \\
\text { assets as measured by net plant to total assets }\end{array}$ \\
\hline LIQ & Sum of cash balances and marketable securities scaled by market value of equity \\
\hline STABDIV & $\begin{array}{l}\text { It is the proxy for past dividend policies. It is a dummy coded variable that takes } \\
\text { a value of } 1 \text { if the dividend payout in } 2013 \text { is } 90 \text { per cent or more of the past two } \\
\text { year's dividend or zero otherwise. }\end{array}$ \\
\hline DER & Three year average of debt equity ratio \\
\hline TOBINQ & Ratio of three year average market capitalization to book value of assets. \\
\hline SG & Average sales growth for three year period. \\
\hline $\mathrm{P} / \mathrm{E}$ & Average price earnings ratio for three year period \\
\hline $\mathrm{P} / \mathrm{B}$ & Average price to book ratio for three year period \\
\hline $\mathrm{CR}$ & Average current ratio for three year period \\
\hline NPR & Average net profit ratio for three year period.Net profit divided by net sales \\
\hline ROI & $\begin{array}{l}\text { Three year average return on investment. Profit before interest divided by capital } \\
\text { employed. Companies don't pay corporate tax in UAE. }\end{array}$ \\
\hline PBIT/TA & $\begin{array}{l}\text { Profit before interest and taxes divided by total assets. Three year average value } \\
\text { was used. }\end{array}$ \\
\hline REE & $\begin{array}{l}\text { Ratio of Retained Earnings to Equity capital of a firm. Three year average value } \\
\text { was used. }\end{array}$ \\
\hline MARCAP & Average Market Capitalization for three year period. \\
\hline
\end{tabular}

\section{References}

Aharony, J. \&Swary, I. (1980). Quarterly Dividend and Earnings Announcements and Stockholders Return: An Empirical Analysis. Journal of Finance, $\quad$ Vol $\quad 35, \quad$ Issue $\quad 1 \quad$ pp. http://dx.doi.org/10.1111/j.1540-6261.1980.tb03466.x

Asquith, P. \& Mullins, D. (1983). The Impact on Initiating Dividends on Stockholder Wealth. Journal of Business, Vol 56, Issue 1, pp. 77-96. http://dx.doi.org/10.1086/296187

Baker, K. Farrelly, G. \& Edelman, R. (1985). A Survey of Management Views on Dividend Policy. Financial Management, Vol 14, Issue 3, pp. 78-84. http://dx.doi.org/10.2307/3665062 
Benito, A. \& Young, G. (2001). Hard Times and Great Expectations? Dividend Omissions and Dividend Cuts by UK firms. Working Paper, Bank of England, ISSN 1368-5562. www.bankofengland.co.uk/archive/.../working papers/2002/wp168.pdf

Bhattacharya, S. (1979). Imperfect Information, Dividend Policy, and the Bird in the Hand Fallacy. Bell Journal of Economics, Vol 10, Issue 1, pp. 259-70. http://dx.doi.org/10.2307/3003330

Brennan, M. (1970). Taxes, Market Valuation, and Corporate Financial Policy. National Tax Journal, Vol 23, Issue 4, pp.

417-427.http://web.b.ebscohost.com/ehost/detail/detail?vid=6\&sid=ba0372af-f123-47ea-bc2e-71806a96eca8\%4 0sessionmgr114\&hid=118\&bdata $=$ JnNpdGU9ZWhvc3QtbGl2ZQ\%3d\%3d\#db=bth\&AN=4587048

Chin, W. Marcolin, B. L. \& Newsted, P. R. (2003). A partial least squares latent variable modeling approach for measuring interaction effects: Results from a Monte Carlo simulation study and an electronic-mail Emotion/Adoption study. Information Systems Research, Vol 14, Issue 2 , pp.189-217. $\mathrm{http}: / / \mathrm{dx}$.doi.org/10.1287/isre.14.2.189.16018

Crutchley, C \& Hansen, R. (1989). A Test of the Agency Theory of Managerial Ownership, Corporate Leverage, and Corporate Dividends. Financial Management, Vol 18, Issue 4, pp. 36-46. http://dx.doi.org/10.2307/3665795

De Angelo, H \& Masulis, R. (1980). Leverage and Dividend Irrelevancy under Corporate and Personal Taxation. Journal of Finance, Vol 35, Issue 2, pp 453-64. http://dx.doi.org/10.1111/j.1540-6261.1980.tb02176.x

Denis David \& Osobov Igor. (2008). Why do firms pay dividends? International evidence on the determinants of dividend policy. Journal of Financial Economics, Vol 89, Issue 1, pp.62-82.

Deshmukh, Sanjay. (2005). The Effect of Asymmetric Information on Dividend Policy. Quarterly Journal of Business \& Economics, Vol 44 Issue 1/2, pp.107-127.

Easterbrook, F. H. (1984). Two Agency Costs Explanations of Dividends. American Economic Review, Vol 74, Issue 4, pp. 650-59.

Elton, E \& Gruber, M. (1970). Marginal Stockholder Tax Rates and the Clientele Effect. Review of Economics and Statistics, Vol 52, Issue 1, pp. 68-74. http://dx.doi.org/10.2307/1927599

Fama E F. (1974). The Empirical Relationships between the dividend and investment decisions of Firms. American Economic Review, Vol 64, Issue 3,pp. 304-318

Fama, E. F. \& Babiak, H. (1968). Dividend Policy: An Empirical Analysis. Journal of the American Statistical Association, Vol 63, Issue 324, pp. 1132-1161. http://dx.doi.org/10.1080/01621459.1968.10480917

Geisser, S. (1975). The Predictive Sample Reuse Method with Applications. Journal of the American Statistical Association. Vol 70, Issue 350, pp. 320-328. http://dx.doi.org/10.1080/01621459.1975.10479865

Gonedes, N. (1978). Corporate Signaling, External Accounting and Capital Market Equilibrium: Evidence on Dividends Income and Extraordinary Items. Journal of Accounting Research. Vol 16, Issue 1, pp. 26-79. http://dx.doi.org/10.2307/2490411

Hair, J. F. Sarstedt , M. Pieper, T. M. \& Ringle, C. M. (2012). The use of partial least squares structural equation modeling in strategic management research: A review of past practices and recommendations for future applications. Long Range Planning, 45, Issue 5/6, pp. 320-340. http://dx.doi.org/10.1016/j.lrp.2012.09.008

Higgins R C. (1972). The Corporate Dividend Saving Decision. Journal of Financial and Quantitative Analysis, Vol 7, Issue 2, pp. 1527-1541. http://dx.doi.org/10.2307/2329932

Hulland, J. (1999). Use of partial least squares (PLS) in strategic management research: A review of four recent studies. Strategic Management Journal, 20, Issue 2, pp.195-204. http://dx.doi.org/10.1002/(SICI)1097-0266(199902)20:2<195::AID-SMJ13>3.0.CO;2-7

Jensen Gerald, R, Solberg Donald, Zorn Thomas. (1992). Simultaneous Determination of Insider Ownership, Debt and Dividend Policies. Journal of Financial and Quantitative Analysis, Vol 27, Issue 2, pp. 247 -263. http://dx.doi.org/10.2307/2331370

Jensen, M \& Meckling, W. (1976).Theory of the Firm: Management Behavior, Agency Costs and Ownership Structure. Journal of Financial Economics, Vol 3, Issue 4, pp. 305-360. http://dx.doi.org/10.1016/0304-405X(76)90026-X 
John, K \& Williams, J. (1985). Dividends, Dilution and Taxes: A Signaling Equilibrium. Journal of Finance, Vol 40, Issue 4, pp. 1053-69. http://dx.doi.org/10.1111/j.1540-6261.1985.tb02363.x

Kale, J. \& Noe, T. (1990). Dividends, Uncertainty and Underwriting Costs under Asymmetric Information. The Journal of Financial Research, Vol 13, Issue 4, pp. 265-77. http://dx.doi.org/10.1111/j.1475-6803.1990.tb00631.x

Kane, A. Young K Lee \& Marcus, A. (1984). Earnings and Dividend Announcements: Is there a Corroboration Effect. Journal of Finance, Vol 39, Issue 4, pp. 1091-99. http://dx.doi.org/10.1111/j.1540-6261.1984.tb03894.x

Kasim Alli, Qayyum Khan, Gabriel Ramirez. (1993). Determinants of Corporate Dividend Policy: A Factorial Analysis. The Financial Review. Vol 28, No 4, pp. 523-547. http://dx.doi.org/10.1111/j.1540-6288.1993.tb01361.x

Kumar, P. (1988). Shareholder-Manager Conflict and the Information Content of Dividends. Review of Financial Studies, Vol 1, Issue 2, pp. 111-36. http://dx.doi.org/10.1093/rfs/1.2.111

Kuo, Jing Ming, Philip Dennis, Zhang Qingjing. (2013). What drives the disappearing dividends phenomena?. Journal of Banking and Finance, , Vol 37, Issue 9 , pp. 3499-3514. http://dx.doi.org/10.1016/j.jbankfin.2013.05.003

Laub, M. (1976). On the Informational Content of Dividends. Journal of Business, Vol 49, Issue 1, pp. 73-80. http://dx.doi.org/10.1086/295811

Linter, J. (1956). Distribution of Incomes of Corporations among Dividends, Retained Earnings and Taxes. The American Economic Review, Vol 46, Issue 2, pp. 97-113.

Litzenberger, R. \& Ramaswamy, K. (1979). The Effect of Personal Taxes and Dividends on Capital Asset Prices: Theory and Empirical Evidence. Journal of Financial Economics, Vol 7, Issue 2, pp. 163-96. http://dx.doi.org/10.1016/0304-405X(79)90012-6

McCabe G M. (1979). The Empirical Relationship between Investment and Financing: A New Look., Journal of Financial and Quantitative Analysis, Vol 14, Issue 1, pp. 119-135. http://dx.doi.org/10.2307/2330658

Miller \& Modigliani. (1961). Dividend Policy, growth and the valuation of shares. Journal of Business, Vol 34, Issue 1,pp. 411-433.

Miller, M. H \& Scholes, M.S. (1978). Dividends and Taxes. Journal of Financial Economics, Vol 6, Issue 4, pp. 333-364. http://dx.doi.org/10.1016/0304-405X(78)90009-0

Myers, S. \& Majluf, S. (1984). Corporate Financing and Investment Decisions When Firms Have Information That Investors Do Not Have. Journal of Financial Economics, Vol 13, Issue 2, pp. 187-221. http://dx.doi.org/10.1016/0304-405X(84)90023-0

Penman, S. (1983). The Predictive Content of Earnings Forecasts and Dividends. Journal of Finance, Vol 38, Issue 4, pp. 1181-1199. http://dx.doi.org/10.1111/j.1540-6261.1983.tb02290.x

Ringle, C. Wende, S. \& Will, A. (2005). SmartPLS, 2.0 (Beta), http://www.smartpls.de, Hamburg.

Rozeff. (1982). Growth, Beta and Agency Costs as determinants of dividend payout ratios. The Journal of Financial Research, Vol 5, Issue 3, pp. 249-259. http://dx.doi.org/10.1111/j.1475-6803.1982.tb00299.x

Sterk, W. \& Vandenberg, P. (1990). The Market Valuation of Cash Dividends and the Tax Differential Theory of Dividend Policy: A Case Revisited. Financial Review, Vol 25, Issue 3, pp. 441-55. http://dx.doi.org/10.1111/j.1540-6288.1990.tb00806.x

Stone, M. (1974). Cross-validatory choice and assessment of statistical predictions. Journal of the Royal Statistical Society. Series B (Methodological), Vol 36, pp.111-147.

Titman, S. \& Wessels, R. (1988). The determinants of capital structure choice. Journal of Finance, Vol 43, Issue 1, pp. 1-19. http://dx.doi.org/10.1111/j.1540-6261.1988.tb02585.x

Watts, R. (1973). The Information Contents of Dividends. Journal of Business. Vol 46, Issue 2, pp. 191-211. http://dx.doi.org/10.1086/295525

Wetzels, M., Odekerken-Schröder, G. \& Van Oppen, Claudia. (2009). Using PLS path modeling for assessing hierarchical construct models: Guidelines and empirical illustration. Management Information Systems, Vol 33, Issue 1, pp.177-195. 